\title{
THE CONCEPTUAL MANAGEMENT FRAMEWORK OF MICROCREDIT PROVIDERS FOR ANTI-POVERTY PROGRAMS: A STUDY ON JOINT AND SEVERAL LIABILITY APPLIED IN MITRA MANINDO COOPERATIVE, NORTH SUMATERA, INDONESIA
}

\author{
Hartanto Arif Dwi*, Susilo, Pratomo Devanto Shasta \\ Faculty of Economics and Business, University of Brawijaya, Indonesia \\ *E-mail: arief.pelukis@yahoo.com
}

\begin{abstract}
Microcredit program has been widely adopted by some coutries to enhance low-end enterprieses which is also a part of anti-poverty program. However, the implementation of microcredit distribution has been criticized for its high number of bad credit cases and lessoptimacy in decreasing the poverty. Those problems have attracted researchers' interest to investigate the ideal management model for microcredit program to decrease poverty cases of the members. This case-study shows that Mitra Manindo Copperative in North Sumatera has successfully decreased the poverty faced by the members through the application of the joint and several liability system (JSL). This JSL model successfully enhance the social power shared among the members by grouping method. Institutional dynamicity of the JSL application has also grown trusts among the members which appeared to be the main input to enhance the social cohesion and social capital. Strong social capital has diseminated various values that enhance the productivity of the members' enterprises. The result of this study can be used as the proliferation in constructing ideal management procedures to apply in microcredit programs by loan providers in order to efficiently and effectively increase members' earnings.
\end{abstract}

\section{KEY WORDS}

Joint and several liability system, organizational managemenet, social cohesion, anti-poverty programs.

Microcredit program is a special program to provide small-scale loan without collateral for people under poverty line or for owners of micro-scale bunsiness to fund their productive activities that give them earnings (Microcredit Summit, 1997). Microcredit have a key role in facilitating people under poverty line to provide them access to get affordable financial aids (Nghiem, 2015). Ease of financial access is an important factor that enhances entrepreneurship and as an instrument of mankind empowerment (Sabatini, Modena\& Tortia, 2011; Abraham\& Balogun, 2012). Those functions are quite beneficial to help the poor people to earn higher income and to support them to live independently. These benefits are important to support the success of anti-poverty programs.

Indonesia is one of countries with the fastest microcredit growth as stated by the Microfinance Market Outlook (2014) that the growth reached around 25-25\%, as high as China, India, Bangladesh, Vietnam and Srilanka. This view is also supported by Rahmawati (2015) who added that beginning in the 1990s, microcredit programs have grown rapidly.

However, the expansive microcredit programs applied by Indonesia suffers from relatively high Non Performing Loan (NPL). As released by Bank Indonesia (2016), the average value of NPL of microcredit had been increasing during 20117-2016 reaching up to $4.5 \%$. High number of NPL triggered lower multiplier effect for microcredit program which also obstructed the acceleration of anti-poverty program. Additional microcredit amount given to 6.36 millions new debitors during 2012-2014 only decreased 274.6 thousands people under poverty line. Thus, it can be implied that to let 1 person free from poverty, there has to be 23 new microcredit new debitors which means that the attempt to decrease the number of poverty through microcredit distribution still requires high cost (high cost economy).

The problems stated above appeared due to the difficulties faced by microcredit providers in Indonesia in implemeting good management since most of providers mainly 
consider to the fulfillment of potential business requirements in distributing the loans (Antondi et.al., 2011). As stated by Amin, Ashok\& Giorgio (2003), microcredit distribution mostly focuses only on the banking model in which the debitors are required to have relatively settled and potential business instead of focusing on how to make the business grow. Lang\& Roessl (2012) argued that the model of loans channeling which does not quite different from bank system is a real proof that competition among microcredit providers is still dominant. The standard micro economy analysis only focuses on its hypothesis related to the institutions which are exclusively run by individuals without considering the aspect of collective business (Valentinov, 2004; Antoldi et.al, 2011). Whilst, Lehner (2011) stated that microcredit providers are supposed to be special collective organizations which focuses on empowering the human in their social structure that is different from capitalistic organization such as banks.

The ideal management system of microcredit program should be able to accommodate the potency of economic capital and social capital at the same time. As stated by Chowbury (2009) and Riemsdijk (2012) that the ideal management of mircoloans programs should be based on two elements which are: (i) management system that is able to improve members' economic scale; and (ii) management system that strengthen the social capital among the members in order to support the members' performance through empowerment programs. Morduch (2005) stated that joint responsibility or Joint and Several Liability (JSL) is the most ideal system yet it is also the most difficult one to apply. This model was introduced by Muhammad Yunus and was firstly applied by Grameen Bank in Bangladesh as a pinoneer model of the world's microcredit programs. JSL is a combination between members' rights and liabilities, which has been proven to be a good option in the management of loaning risks. The implementation of JSL includes some processes; decision-making, financial problem solving, risk anticipation, and collaboration in dealing with liabilities.

It is stated by Hutagaol et.al (2011) that JSL is system that is full of dynamicities which puts the collaboration at the top, especially in decision making. There are also some views which claim that the social effect of JSL provides relevant effect toward the social cohesion and anti-poverty programs (Bharadwaj, 2012). This model has been considered to have effectiveness in accommodating economic capital and social capital at the same time which enables the providers to have good guarantee of loan risks and allows the providers to help the members improving their productive business, making the empowerment program run optimally.

Based on the explanation above, a good understanding on the ideal management of microcredit program management is needed. It is also necessary to contribute theories for the literatures on the meaning and the role of construction of microloan programs as antipoverty program. In this context, the success of anti-poverty program is indicated by the improvement on members' earnings.

Regarding to those facts, this study was intented to give contributions for better insights on ideal manangement system of microcredit program as a part of anti-poverty programs. To obtain good understanding of this matter, a conceptual framework needed to develop. This study focuses on the use JSL as the most ideal system to improve members' earnings. Besides this model believed as an effective way to improve members' earnings, it has believed that it also decrease the number of NPL up to zero percent for this model is able to apply empowerment mechanism that is able to manage the economic aspects and social capital at the same time. Thus, this study was considered necessary to conduct.

Analytical Model Development. The objective of this study is to develop a conceptual framework of microcredit programs as a part of anti-poverty program. In this study, the conceptual framework was developed based on the joint and several liability (JSL) model of microcredit distribution. There are some aspects to analyze precisely through organizational theory approach such as transaction, rules and empowerment aspects. Some of these organizational approaches integrated to each other that formed a certain management system that covers people under the poverty line as the segment of microcredit market to be empowered that would also improve their life as the members of the cooperative. This principles are important keys to the ideal management of microcredit program. This 
management system is operated through this analysis model development as seen from Figure 1.

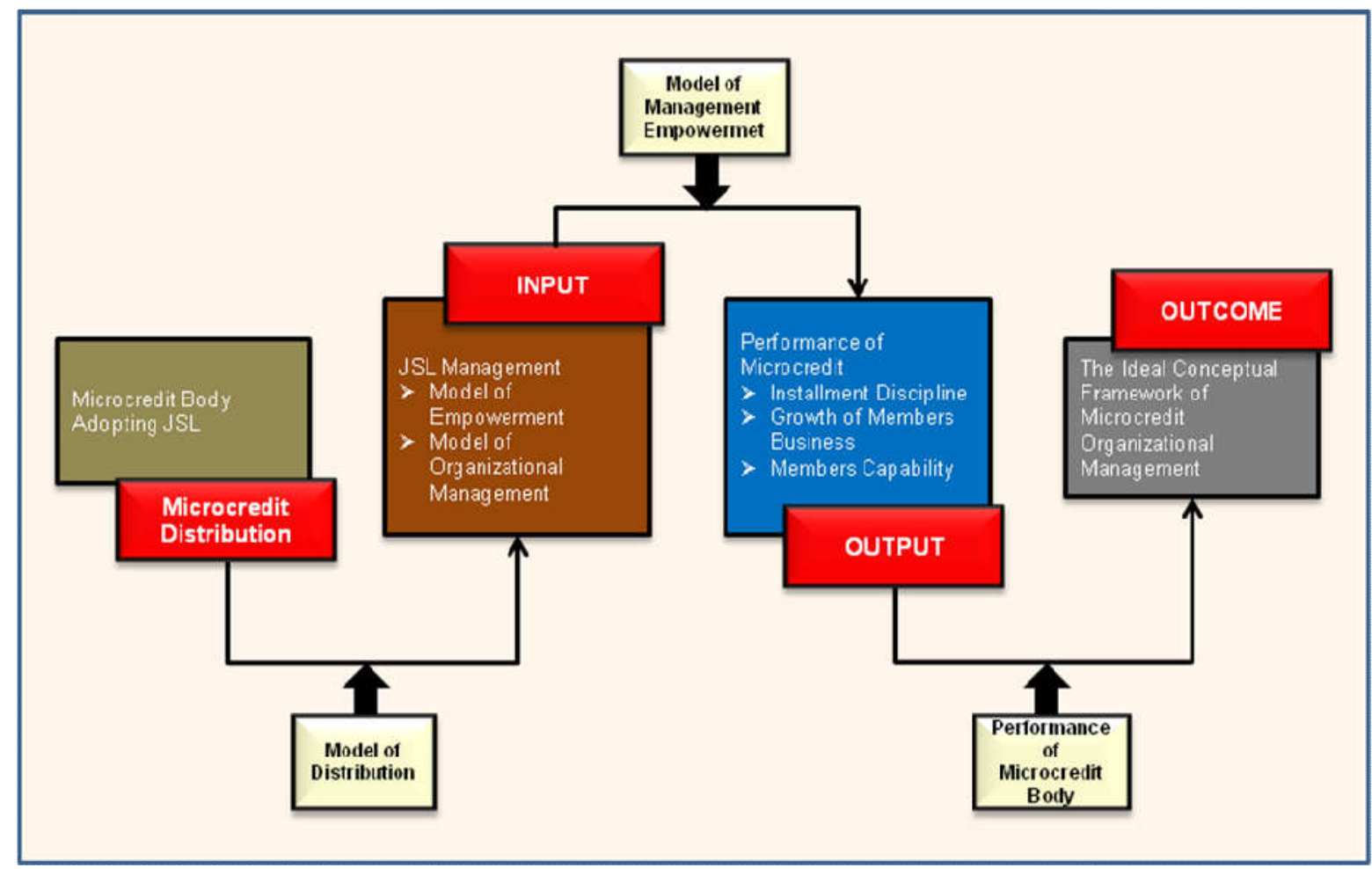

Figure 1 - Analytical Model

Based on Figure 1, the distribution of microcredit can be assessed from the channeling method. This channeling method leads to the management system of JSL applied in microcredit providers. The management of JSL is seen as an input which consists of two components: the organizational management and empowerment model. Those two aspects are assessed and evaluated to see if the providers have given enough support to the success of the management. After that, the output is assessed which refers to the level of achievement. The achievement refers to three aspects: the installment discipline, the growth of members' business, and empowerment aspect. This achievement is also regarded as an empirical model, which is then strengthened by thorough critical analysis on the literatures. The combination between those two analyses expected to construct an ideal organizational conceptual framework for microcredit programs as a part of anti-poverty programs.

\section{METHODS OF RESEARCH}

\section{Methodological Approach}

To figure out the implementation of JSL management as the source of ideal conceptual framework construction, descriptive qualitative approach was employed considering the following reasons:

1. The use of descriptive qualitative method is relevant with the objective of this study and with the analysis method development, which are necessary to conduct the field study in order to find and understand the JSL management model.

2. Regarding to the point 1 , qualitative approach is the best option when a study needs interpretation and explanation upon certain phenomena or case. Tobin, Begley \& Cecily (2003) also supported the view in which it is stated that qualitative method is necessary to employ if a study requires deep understanding to find, describe and explore certain phenomena in order to figure out the characteristics of the phenomena. 
3. In addition, Schryen, Wagner \& Alexander (2015) also stated that qualitative studies need to be strengthened with critical literature review as the contribution to develop the empirical finding into beneficial theories. The use of literature study was based on the fact that this study involves various applied elements which can be explored through deep and intensive literature review.

Regarding to those reasons (emphasis on point 1 and point 2), descriptive qualitative method was used through empirical investigation construction (direct observation) under the case-study approach. Case-study apporach is considered appropriate to be applied in this study since the objective of this study is to obtain deeper understanding toward the phenomena of the use of JSL organizational management. Based on the reason stated in point 3 , the case-study used in this study is completed with critical literature review. The combination between case-study and critical literature review makes an integrated unity that results to a representative conceptual framework on the organizational management of microcredit program as the part of anti-poverty program.

Case-Study Approach. This study was done by conducting field studies in order to understand the JSL model through in-depth analysis and exploration. Field study was conducted from time to time which required detail and deep data collection from various sources (observation and in-depth interview). Some techniques were used to make the casestudy approach in this study more operational including:

1. Regarding to a number of previous studies, case-study approach is better applied through the human behavioral perspective to picture out and explain human interaction. Human behavioral perspective should be adjusted to the scope of the case to determine if the interaction involves an individual, some individuals, a group of individuals, the whole group or just an activity.

2. According to Hsieh\& Shannon (2005), qualitative approach applied through human behavioral perspective should employ interview and observation methods. This technique has been used by previous reseachers such as Khavul, Chavez,\& Bruton (2013) who conducted a study on institutional changes by observing the interactional dynamicity among the subjects. Chloupkova, Haase\& Svendsen (2003) have also identified that to see if microcredit providers have successfully developed innovative programs to improve members' welfare can only be done by administering in-depth interview.

3. Regarding those views, the use of case-study in this study aimed at indentifying and understanding different dimensions of a phenomena, meaning and hollistic characteristics of the JSL management. In line with Jailani (2013) who stated that case-study is a type of research approach that aims at investigating certain phenomena in an intensive, in-depth, detail and comprehensive way. In-depth understanding and identification should be done based on empirical investigation to see the reason why and how the JSL management is implemented.

Research Setting and Data Collection. This study employed the criterion based selection to determine the location of the study. This concept was chosen to allow the reseacher selecting certain unique, special and specific characteristics to investigate. The research took place in the Mitra Manindo Cooperative in Mandailing Natal Subdistrict of Norht Sumatera Province. Mitra Manindo Cooperative had been using the JSL management for quite a while and had gone through long dynamic organizational process.

Interviews. Around Feburary-June 2017, in-depth interviews were conducted to the employees and the members of Mitra Manindo Cooperative that involved 8 informants in which each visitation session lasted for averagely 1.5-3 hours within a weekly intensive visit. In administering the interviews, the researcher did not employ structrured interview (adopting the theory of Weis\& Fine, 2000; Morse\& Richards, 2002), yet, the researcher worked under the principles of an ideal research design (adopting Cresswell, 1994). Therefore, better comphesion on the pattern of a meaning was needed to explain the meaning in more concrete elements (Santika, 2016). 
Table 1 - Characterisitics of the Data Source

\begin{tabular}{|c|c|c|c|}
\hline Informant Status & $\begin{array}{l}\text { Number } \\
\text { of interview }\end{array}$ & Interview content & Supporting information \\
\hline $\begin{array}{l}\text { Board } 1 \text { (Chief) } \\
\text { Board } 2 \text { (Vice chief) } \\
\text { Board } 3 \text { (Treasurer) } \\
\text { Board } 4 \text { (Group advisor) }\end{array}$ & $\begin{array}{l}1 \\
2 \\
3 \\
4\end{array}$ & $\begin{array}{ll} & \text { History Mitra Manindo } \\
- & \text { Management system of the } \\
\text { INPUT } \\
\text { INPUation } \\
\text { - } \quad \text { Group mechanism } \\
\text { OUTPUT } \\
\text { OUTPCtion and transaction } \\
\text { - } \quad \text { Member participation } \\
\text { Activities and programs of } \\
\text { OUTCOME } \\
\text { - SHU (surplus) } \\
-\quad \text { Member welfare } \\
-\quad \text { Performance of the } \\
\quad \text { cooperation }\end{array}$ & $\begin{array}{ll}\text { - } & \text { Cooperation documentation } \\
\text { - } & \text { Shoji et.al (2012) about social capital } \\
\text { fomatioon to credit access; } \\
\text { Hashemi\& Schuler (1996) about STR } \\
\text { at Grameen Bank Bangladesh } \\
\text { - } \quad \text { Ministry of Cooperation and Micro } \\
\text { Industries } \\
\text { - www.gemari.com, Independepent } \\
\text { Family Magazine } \\
\text { - Expert informant and FGD among } \\
\text { experts }\end{array}$ \\
\hline Member 1 (Group leader) & 5 & $\begin{array}{l}\text { INPUT } \\
-\quad \text { Group mechanism } \\
\text { - Interaction and transaction } \\
\text { OUTPUT } \\
-\quad \text { Member participation } \\
-\quad \text { Activities and programs of } \\
\quad \text { the groups } \\
\text { OUTCOME } \\
-\quad \text { Member welfare }\end{array}$ & $\begin{array}{ll}\text { - } & \begin{array}{l}\text { Cooperation and group } \\
\text { documentation }\end{array} \\
\text { - } & \text { Shoji et.al (2012) about social capital } \\
\text { fomatioon to credit access; } \\
\text { Hashemi\& Schuler (1996) about STR } \\
\text { at Grameen Bank Bangladesh } \\
\text { - Expert informant and FGD among } \\
\text { experts }\end{array}$ \\
\hline $\begin{array}{l}\text { Member } 2 \text { (Group member) } \\
\text { Member } 3 \text { (Group member) }\end{array}$ & $\begin{array}{l}6 \\
7\end{array}$ & $\begin{array}{ll}\text { - } & \text { Perspective toward groups } \\
\text { and personal benefits } \\
\text { - } & \text { Fundings } \\
\text { - } & \text { Member commitment }\end{array}$ & $\begin{array}{l}\text { - Shoji et.al (2012) about social capital } \\
\text { fomatioon to credit access; } \\
\text { Hashemi\& Schuler (1996) about STR } \\
\text { at Grameen Bank Bangladesh } \\
\text { - Expert informant and FGD among } \\
\text { experts }\end{array}$ \\
\hline
\end{tabular}

Intervieweesю There were eight informants who participated in this study, which means that the minimum five samples requirement has been fulfilled (Khavul, Chavez \& Bruton, 2013). In addition, the researcher also regarded various perspectives and set an independent statement as a control for each of the category. The intensity of the interview was determined based on the complexity of each theme and case. In order to anticipate the gap on the recorded data by some data collectors, the researcher conducted follow-up questionings through phone calls and email. As an attempt to respect the research ethic, the respondents were labelled as employee 1 , employee 2 , member 1 , member 2 , and so on.

Triangulationю The purpose of triangulation in this study is to ensure validity of the data as researcher use qualitative performance. In this study, the researcher used materials from the archive (recording interviews, discussions and documentations) to perform triangulation. In a case study by using content analysis, triangulation was obtained from Mitra Manindo documentations. On the field, researcher discovered Mitra Manindo documentation archives (since the initial application of STR 1990 to 2017) to allow researcher to reconstruct the sequence from the beginning of time, the process of changing institutional arrangements, to connect different roles of the actors from time to time. This document was very beneficial in providing a perspective toward the information from the informants, thus enabling researcher to ask questions interrogation (probing) and provide additional guidance in making a list of questions.

Operationally, triangulation in this study was the multimetode approach conducted by researcher at the time of collecting as well as analyzing the data. The validity of the data from one informant should be confirmed with data obtained from other informants and other researcher (using colleagues / other researcher in the field and then FGD (Focus Group Discussion)). Then, each informant would serve as controller to one informant and other informants (adopting Santika, 2010). This controls was conducted through four approaches: (i) based on triangulation theory (combining a number of theories of critical literature that researcher), (ii) triangulation method (using the content analysis method and naturalistic 
empirical findings from the development of grounded theory), and (iii) data triangulation (obtaining data from various cases and sites as in Table 1).

\section{RESULTS OF STUDY}

This study was intended to construct an analysis model (Figure 1) and explore it to see the organizational dynamicity of JSL system applied in Mitra Manindo Cooperative which successfully improved members' earning through the implementation of empowerment scheme. The organizational dynamicity of JSL was observed from the first step of construction, development up to empowermrnet, making the JSL an ideal management used to solve members' problems related to poverty. The focus of the analysis as the construction of the organizational conceptual framework was directed at the organizational dynamicity of JSL which had certain implication on the determination of certain program to improve members' earning.

Organizational Dynamicity of the Construction of Joint and Several Liability in Mitra Manindo Cooperative. Based on the result of field study, the organizational dynamicity of JSL in Mitra Manindo Cooperative could be chuncked into three steps; initial step, bounding step and empowerment step. Those three steps worked in a dynamicity, followed by modifications on some managerial components which in this study is categorized as the process to discover appropriate organizational management. In the initial step, JSL was chosen as an agreed option by the intern members of the cooperative as a strategy to reduce the number of non performing loan and as a way of empowering the members. In the bounding step, the JSL slowly became a system that bounded the members for it provided the feeling of togetherness. In the empowerment step, JSL has become an inseparable part of members' business because of the cohesiveness created by JSL activities.

Initial Step: Joint and Several Liabilities as a Chosen Management System of Microcredit Channeling. Mitra Manindo Cooperative is one of leading cooperatives that implements Joint and Several Liability (JSL) system in the western part of Indonesia, particularly in Sumatera. The implementation of JSL was inspired by the success of Grameen Bank in Bangladesh, established by Muhammad Yunus in setting the people free from poverty. Specifically, the construction of JSL in Mitra Manindo Cooperative is explained as follows.

1. The segmentation of Mitra Manindo Copprative members are women because females were believed to have stronger solidarity than males. This gender unique gender characteristic found in women has become the biggest motivation to implement the JSL system.

2. Basically, JSL was implemented in a group of people (in North Sumatera local language is called as Poken), in which each group (Poken) consisted of 15 to 40 members. The members of a group should know each other or lived around the same neighborhood to minimize the change of asymmetric information sharing and moral hazard among the members.

3. One group (Poken) was chuncked into several smaller groups which one group consisted of 5 members. In this small group, there was 1 leader, 1 co-leader and 3 members. The function of the leader and co-leader was to conduct coordination and monitoring of members business activity under the same small group or big group (Poken).

4. Members of the same small group and big group (Poken) were responsible to conduct coordination and take the risk of the JSL system if any of the member could not pay installments. Members were also required to do monitoring upon members' business activities. These obligations were intended to reduce the chance of any assymetrical information and conduct effective and efficient supervision in monitoring micro-scale business activity which is known of containing high risk of failure.

Some of those steps of JSL implementation have been considered appropriate with the basic principles of cooperative, namely, collaboration (gotong royong), kinship, and togetherness that strengthen members' brotherhood and enhance social awareness and 
teach how to socialize effectively within a group (Indriyo, 2006). The early concept used by Mitra Manindo Cooperative to create strong JSL system was inspired by women living in villages who liked to gather with each other and created strong bounding among them (Employee \#1). This system is expected to give positive effect toward the behavior and attitude of Mitra Manindo Cooperative Members in order to prevent them from performing any moral hazard actions which might give negative effects on their productive business activities.

Bounding Step: Joint and Several Liability as an Informal System in Building Social Cohesiveness. The function of grouping in JSL is allowing conscious internalization of values and results of an action that contribute to stronger emotional bounding, better performance and inseparable togetherness. These values were obtained because there were some ideas and steps applied in the construction of JSL system which occurred within three processes: (i) Making anticipation of possible problems; (ii) Constructing an appropriate system; (iii) Implementation of the system. These steps have successfully created essential changes on members' behavior which reconstructed the culture of a group. This finding is consistent with the findings of some previous researchers who discovered the way cooperative development based on informal social relationship gives better supports for better organizational system, especially in reducing the amount of non-performing loan (Lyon, 2000)

Empowerment Step: Attempt to Shift the Informal System to Logical System Based on Voluntarily (Voluntary System). The next step occurred in the JSL process was strengthened cohesiveness among the members either within small groups or bigger groups (Poken). This could occur because of some JSL activities: (i) The grouping in JSL constructed a community that essesntialy consisted of various different personalities and extern factors; and (ii) Diffusion occurred in which trust and solidarity were strengthened due to intensive meetings to construct synergic solidarity from the members' familiarity. This implies that there were coordinations within a group in which the cooperative's employees who also held structural duties and functioned as a control in the group (employee \#1; \#2; member \#1). This formal group then created direct rule enhancement of the cooperative management and its entrepreneurship aspect. This rule enhancement directly played an important role as a control upon any members' activities related to the loan channeling and business activities.

Organizational Dynamicity of the Joint and Several Liability System and Its Implication toward the Social Cohesiveness. The steps of JSL construction as explained above indicate that there should be an important bounding made among organizations which transform into formal logic based on voluntary system as the result of trust sharing and intensive teamwork. This fact cannot be separated apart form the intensive interaction in the small group and in the bigger group (Poken) which has successfully created strong and well-planned social cohesiveness. In the practice of JSL system, group activities play major roles in creating strong feeling of togetherness which enhances group cohesiveness. When new members came into a group, all of the other members were required to make agreements based on the level of trust toward the new members (Employee \#1). This level of trust is enhanced through intense interaction and group-value orientation given to the new members. At this point, interactional bound is regarded as a social bound which has been proven by some empirical studies that it shares strong relationship with social cohesiveness (Munshid Bin Harun\& Mahmood, 2012). In Mitra Manindo Cooperative, members' participation within a group interaction has grown stronger group cohesiveness which resulted to significant enhancement on organizational performance and on members' business activities (Employee \#1). This finding supports the ones found by Mullen\& Cooper (1994) and Loughead\& Carron (2004) in which group cohesiveness and group activities are effective in creating social cohesiveness which enhances the productivity of certain business performance. This view is an important fiding that better productive economic performance can be created by well-planned social activities which enhance cohesiveness among the members.

Important Role of the Institutionl Entrepreneurs. The success of JSL system in reducing the amount of non peforming loans and creating social cohensiveness among members cannot be separated apart from the good job performed by the employees of the cooperative. 
Seen from the theory of institutional economics, important figures behind the success of the management are called institutional businessman. Some experts define institutional businessman as a collective action regardless of the number of people in it (Khavul, Chavez\& Bruton, 2013). In the context of Mitra Manindo Cooperative, institutional businessman refer to the employees of the cooperative, especially the pioneer of the JSL system. Employees of the cooperative were selected by the members of the cooperative as the representatives of the members in any organizational activities and cooperative activities as well. Within this context, employees of the cooperative function themselves as a professional organization which make efforts to effectively and efficiently develop the cooperative's business activities by empowering members' potencies, resources, commodity, and make future plan for the sustainability of the cooperative (Employee \#1). Hence, the role of the employees is quite essential to the development of the cooperative. This fact supports the argument that agent of change which consists of members, especially employees, owns a central function in creating innovations for the organizational environment (Khavul, Chavez\& Bruton, 2013).

Institutional businessman is able to direct any institutions such as Mitra Manindo Copperative as the architect of social innovations since they administer economic activities not only by enhancing the existing institutional environment, but also by creating new institutional environment (Phillip, Lawrence\& Hardy, 2004). In line with the definition of Schumpeter (in Novkovic, 2008) that entrepreneurship is a process that creates values as the product of innovation. Institutional entrepreneurship in Mitra Manindo Cooperative was created by the efforts made to create better social values (in the determination of rules and management procedure of JSL) through innovations. This finding is also in line with a view proposed by Novkovic (2008) that institutional businessman refers to the actors that create social values through innovations.

\section{DISCUSSION OF RESULTS}

The Process of Institutional Management in the Joint and Several Liability System in Enhancing Social Cohesiveness among Members. The process of institutional change in implementing the JSL system as stated in the previous session consists of three parts:

1. Historically, JSL system has gone through dinamicity started from the early phase of Mitra Manindo Cooperative development up to today's existing condition. This fact shows that there have been efforts made to redefine the institutional logic that emphasizes on the modification of the management to reach the expected management model.

2. The use of JSL has grown social cohesiveness. Enhancement on the social cohesiveness is important in enhancing social capital from the group cohesiveness, strong bounding among members and employees within the determined coopeartive's programs and activities (Munshid Bin Harun\& Mahmood, 2012).

3. Those steps cannot be separated apart from the important role of institutional businessman or the employee of Mitra Manindo Cooperative. Institutional businessman hold the key role in connecting organizational changes to form wellestablished institutional management that strengthens the social cohesion among members.

Those three elements are closely related to the characteristics of Mitra Manindo Cooperative which is an entity in the form of an entrepreneurship-based cooperative that was formed with trust among the members. Strong feeling of trust has been successfully nurtured by intensive intearaction among the members as facilitated by the JSL system. Members interpret trust within the JSL system as a "belief upon each member's competence" (Employee \#1). As explained in previous studies, trust rises and operates when members share a positive belief with each other (Misztal, 1996; Farrell\& Knight, 2003). Tust in JSL also rises out of norms and moral moral formation within a social network. Trust itself is also an intergral part of social capital which holds an important role in managing more productive economic activities (Lyon, 2000). These various findings have created a curve on how to 
conduct organizational amangement, involving various factors that give positive contribution toward stronger function of social capital as presented in Figure 2.

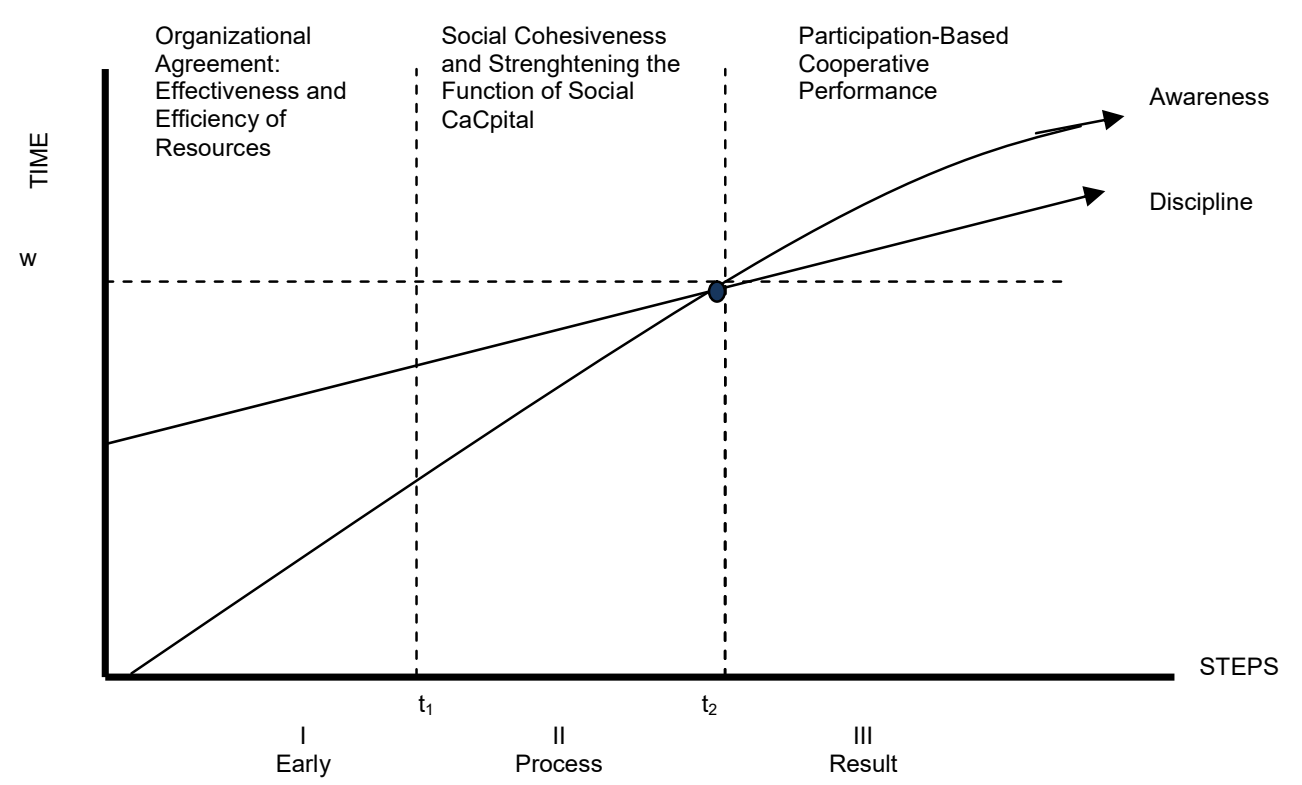

Source: Modified from the Idea Development Majee \& Hoyt (2011); and Reseachers' View based on the Reseach Result.

Figure 2 - Steps of Organizational Management, Strengthening the Function of Social Capital, and Cooperative Performance

Step I was the process of organizational management in Mitra Manindo Cooperative, in which the implementation of JSL required members' discipline upon the rules applied by the cooperative. This step emphasized on how the rules were applied based on the agreed values. The step II was the process of discipline enhancement and members' attitude assessment. The transformation of organizational management to the strengthened function of social capital was abridged by the trust. The movement from the phase I and II which is bordered by line $t_{1}$ shows the early stage in which the curve of members' awareness is still under the curve of discipline which implies that coercive elements are still used as the rule intervention done by the cooperative. Whilst, in the phase III, the result appears in which the function of social capital is strengthened as the result of good organizational management that contributes to better cooperative performance and better productivity of members' business. In this phase, members are expected to grow awareness that rules are not coercive elements, instead rules are necessities in the form of strong awareness toward values applied in JSL.

The strengthened trust and social capital in JSL were created by the accumulation of beliefs formed by the organizational management applied by the cooperative. Therefore, at this point, the intersection of line $t_{2}$ and $w$ is the meeting line of awareness curve which is located above the discipline curve. Hence, in this context, members' awareness can turn into voluntary system within the participatory cooperative operation. It goes in line with the view that voluntary associations are believed to come from the important role held by social capital development (Wollebaek \& Selle, 2003; Majee \& Hoyt, 2011).

Social Cohesiveness and Its Implication toward Members' Business Empowerment. The development of members' business as the result of JSL implementation is an interesting phenomena related to how organizational management empowers social cohesion that has some implications toward members' business activity. As stated in some theoretical studies, social cohesion stimulates member to contributes any resources for new things and creates new values (Utama, 2003). This social cohesion is identical to the social capital which is regarded as an input of production factors besides physical and financial capital. This finding goes consistently with the one stated by Sumarti (2007) that optimal economic activities are 
closely related to the objectives of an interaction based on social capital which forms basic social potencies.

Some relationship pattern in enhancing social capital through the implementation of JSL gives important construction for how Mitra Manindo Cooperative implements adjustment process within the grouping of social networking based on social capital. In line with Jiang (2009), social capital offers accessibility of resource integration including input, process and output. Therfore, social capital can also be used to create a more innovative environment. Social capita also has positive effect toward members' business activity for it affects production cost and exchanges which stimulate more productive environment. More productive institution also stimulates more ideas, beliefs and actions of the organization (Greenwood \& Suddaby, 2006). Thus, a view proposed by previous researchers is considered true in which it is stated that determining appropriate organizational management in the management of cooperative is as important as obtaining appropriate incentive for the development of the cooperative (B. Barret, R. Lee\& G. McPeak, 2005).

Meanwhile, organizational dynamicity that occurs in JSL basically creates potential business network for the members. For instance, members exchange information related to their business which creates open market information, including the introduction of extern netrowk outside JSL members. The benefits offered by strong social cohesiveness for members of Mitra Manindo Cooperation can be classified into three parts:

1. Social cohesiveness in JSL is able to create business efficiency my minimizing transaction costs.

Generally, frequently occured transaction costs in micro-scale business are: (i) cost for information seeking, (ii) cost of creation, implementation and monitoring of contract, (iii) waiting cost in conducting production from a period to other periods, (iv) managerial cost, and (v) cost of distribution activities. In fact, before becoming the members of Mitra Manindo Cooperative, they used to find difficulties in obtaining information, especially information related to business input up to information on product marketing with appropriate price. When they found difficulties in obtaining information, most members got some more problems due to assymetrical information that gave negative effects toward the long-term business development. Fortunately, after joining Mitra Manindo Cooperative, they received cohesive information within a clear work contract with input supplier and with the output consumers as well. This action was done to guarantee members' business sustainability. With a clear contract, members are given guarantees that their business run well in the future. Networking in JSL also facilitas teamwork that rises transaction efficiency which is also a solution toward market imperfections for both micro-scale and macro-scale business.

2. Social cohesiveness in JSL improves accessibility toward business capital.

The level of business capital accessibility in micro-scale business is considered relatively low seen from start-up capital and access of long-term capital for investment. In order to improve the start-up capital, networking in JSL involves three aspects which includes financial aids, technical supports, and business-security program. In the other hand, to improve the accessibility toward business capital, members of the cooperative were motivated to provide aids for other members in need, which also appears as a solution for members with limited resources in accessing bank loan. This phenomena also becomes social guarantee shared among JSL members.

3. Social cohesiveness in JSL creates innovative business climate.

Before becoming members of Mitra Manindo Cooperative, most micro-scale businessman always faced problems related to mainstream limitations in managing their products. After joining the cooperative, members get an ease of access toward better marketing, better product management and production, and product innovation. In this context, networking also appears as a process to create more innovative business environment which cannot be separated apart from the ability of the network to stimulate innovations, higher product values, and provide wider job opportunity (Muresan\& Gogu, 2012). This phenomena also has some implications toward the performance of members' business because it has some effects on production and exchange costs. Productive organizational environemtn also stimulates more ideas, beliefs and actions used either 
formally or informally by the emembers. The role of this local business network is important in information and knowledge sharing as well as in creating innovative business climate as stated by Doloreux\& Parto, (2005) who mentioned knowledge transfer as specific resource (local competence, skill, institution, and other cultural and social values). Specific resource triggers innovation and better organizational competitiveness. This dynamicity affects the social and organizational condition that rise discovery of new concepts in planning the improvement of local organizational competitiveness in the form of learning region, innovative milieu, industrial district, and local productive system.

\section{CONTRIBUTIONS AND CONCLUSION}

The result of this study shows that the success of organizational management of JSL system is strongly bounded to three factors; (i) the existence of organizational dynamicity; (ii) social cohesiveness; and (iii) the role of institutional entrepreneurs. The strength of JSL system comes from the values, rules, norms and more importantly the trust shared among the members. This study proposed the view that there is a causal connection between the determination of organizational management and trust improvement. It shows that besides transaction characteristics, organizational management is an inseparable part of values and norms which strongly affect the mode choice of the cohesiveness and social capital development. Unlike other organization, Mitra Manindo Cooperative implements JSL system which successfully enhances stronger social trust.

The contribution of this study is mainly answering the debate about trust which has multi-phase characteristics. This question has been answered by argumentation and empirical tests presented in this study, in which it is found that strong trust can be constructed through precise organizational management. The result of this study also indicates strong relationship between organizational management and improvement of the functions of social capital. Therefore, the debate about the function of trust in cooperative which includes: (i) where does trust as a basic proposition of social capital come from?; and (ii) is social trust within the environment of cooperative a precondition of social capital or is it a product of social capital. Based on the result of this study, trust appears as a precondition of social capital. In this context, social capital is created from an appropriate organizational management applied in an institution or in another word, trust accumulates the social capital. Within the context of cooperative economics, the development of social capital is an important base to contruct an ideal cooperative as a part of anti-poverty program.

\section{REFERENCES}

1. Abraham, H; Balogun, L.O. 2012. Contribution of microfinance to GDP in Ingeria: is there any?. International Journal of Business and Social Science, Vol. 3, No. 17, pp. 167-176.

2. Amin, Sajeda; Ashok S Rai; and Giorgio Topa. 2003. Does microcredit reach the poor and vulnerable? Evidence from northern Bangladesh. Journal of Development Economics, Vol, 70, No. 1, pp. 59-82.

3. Antoldi et al., 2011. Strategic Networks, Trust and the Competitive Advantage of SMEs. DOI, Springer-Verlag Berlin Heidelberg, 10.1007.

4. Bank Indonesia. 2016. Data Kredit Usaha Mikro, Kecil dan Menengah (Metadata).

5. Barret, Christopher; Lee, David R\& McPeak, John G. 2005. Institutional Arrangements for Rural Poverty Reduction and Resource Conservation. World Development, Vol. 33 No. 2, pp. 193-197.

6. Bharadwaj, Bishal. 2012. Roles of Coopetaivenes in Poverty Reduction: A Cse of Nepal. Administration and Management Review, Vol. 24, No. 1.

7. Chloupkova, J., Haase Svendsen, G.L., Svendsen, G.T. 2003. Building and Destroying Social Capital: The Case of Cooperative Movements in Denmark and Poland. Agricultural and Human Values, Vol. 20, pp. 241-252.

8. Chowdbury, Anis. 2009. Microfinance as a poverty reduction tool-a critical assessment. DESA Working Paper No. 89. New York: USA. 
9. Creswell, John W. 1994. Research Design: Qualitative and Quantitative Approaches. California: Sage Publications, Inc.

10. Doloreux, D. 2004. Regional Networks of Small and Medium Sized Enterprises: Evidence from the Metropolitan Area of Ottawa in Canada. European Planning Studies, Vol. 12, No. 2, pp. 173-189.

11. Farrel, H.\& Knight, J. 2003. Trust, Institutions, and Institutional Change: Industrial Districts and the Social Capital Hypothesis. Politics\& Society, Vol. 31, No.4, pp. 537-566.

12. Greenwood, R., Suddaby, R., 2006. Institutional Entrepreneurship in Mature Fields: the Big Five Accounting Firms. Academy of Management Journal Vol. 49, No. 1, pp. 27-48.

13. Hashemi, S.M. et al 1996. Rural Credit Programs and Women's Empowerement in Bangladesh. World Development, Vol. 24, No. 4, pp. 635-653.

14. Hsieh, H.-F., \& Shannon, S.E. 2005. Three approaches to qualitative content analysis. Qualitative Health Research, Vol. 15, No. 9, pp. 1277-1288.

15. Hutagaol, P., et all. 2011. Analisis Daya Saing Susu Murni Produksi Koperasi dan Formulasi Kebijakan Peningkatan Daya Saingnya di Pasar Dalam Negeri: Studi Kasus Pada Koperasi Susu di Provinsi Jawa Barat. Jurnal Ekonomi. Vol. XXI. No. 2, 60-77.

16. Indriyo, Daru. 2006. Rahasia Sukses Tanggung Renteng Membangun Bisnis. Bekasi: FORest Press.

17. Jailani, Syahran. 2013. Ragam penelitian qualitative (ethnografi, fenomenologi, grounded theory, dan studi kasus). Edu-Bio, Vol. 4, pp. 41-50.

18. Jiang, B. 2009. Flexible Business Process Integration for Clusters of Small-Medium Sized Enterprises in Heterogenous Environment. Journal of Software. Vol. 4, No. 4, June.

19. Khavul, Susanna; Chaves, Helmuth; Brutton, Garry D. 2013. When Institutional Change Outruns the Change Agent: The Contested Terrain of Entrepreneurial Microfinance for Those in Poverty. Journal of Business Venturing, Vol. 28, pp. 30-50.

20. Lang, Richard; Roessl, Dietmar. 2012. The Role of Social Capital in the Development of Community-Based Cooperatives. Research Institute: Vienna.

21. Lehner, Othmar M. 2011. The Phenomenon of Social Enterprise in Austria: A Triangulated Descriptive Study. Journal of Social Entrepreneurship, Vol. 2, No. 1, pp. 5378.

22. Loughead, T.M., \& Carron, A.V. 2004. The Mediating Role of Cohesion in the Leader Behavior- Satisfaction Relationship. Psychology of Sport and Exercises, 5, 355- 371.

23. Lyon, Fergus. 2000. Trust, Networks and Norms: The Creation of Social Capital in Agricultural Economies in Ghana. World Development, Vol. 28, No, 4, pp. 663-681.

24. Majee, W. et al 2011. Cooperatives and Community Development: A Perspective on the Use of Cooperatives in Development. Journal of Community Practice, Vol. 19, No. 1, pp. 48-61.

25. Misztal, B. A. 1996. Trust. Cambridge: Polity Press.

26. Microcredit Summit. 1997. The Microcredit Summit Report. Spain.

27. Microfinance Market Outlook. 2014. Josefstrasse: Zurich, Switzerland.

28. Morduch, Jonathan. 2005. The Economics of Microfinance. The MIT Press: Cambridge, Massachusetss, London.

29. Morse, J. M., \& Richards, L. 2002. Readme First for a User's Guide to Qualitative Methods. Thousand Oaks, CA: Sage.

30. Mullen, B., \& Copper, C. 1994. The Relation Between Group Cohesiveness and Performance: Integration. Psychological Bulletin, Vol. 115, No. 2, pp. 210-227.

31. Munshid Bin Harun, M.Z\& Mahmood, R.B. 2012. The Relationship Between Group Cohesiveness and Performance: An Empirical Study of Cooperatives Movement in Malaysia. International Journal of Cooperative Studies, Vol. 1, No. 1, pp. 15-20.

32. Muresan, M., Gogu, E. 2012. SMEs Public Involvement in the Regional Sustainable Development. Procedia Social and Behavioral Sciences. Vol. 62, 253-257.

33. Nghiem, Hong Son. 2015. Analysisng the Effectiveness of Microfinance in Vietnam: A Conceptual Framework. School of Economics University of Queensland.

34. Novkovic, Sonja. 2008. Defining the Cooperative Difference. The Journal of SocioEconomics, Vol. 37, 2168-2177. 
35. Phillips, N., Lawrence, T., Hardy, C., 2004. Discourse and Institutions. Academy of Management Review, Vol. 29, No. 4, pp. 1-18.

36. Riemsdijk, van Micheline. 2012. Critique of Microcredit as a development model. Pursuit: The Journal of Undergraduate, Vol. 4, No. 1, pp. 109-117.

37. Sabatini, Fabio; Modena, Fransesca; Tortia, Ermanno. 2011. Do Cooperative Enterprises Create Social Trust?. European Research Institute on Cooperative and Social Enterprises (Euricse): Trento.

38. Santika, I Putu. 2010. Makna Hubungan Sosial Petugas Kredit dan Pengaruhnya Terhadap Perilaku Nasabah dalam Mengembalikan Kredit, Suatu Tinjauan dari Perspektif Teori Modal Sosial (Studi pada Nasabah Kupedes Bank Rakyat Indonesia Unit Poncokusumo-Kabupaten Malang. Disertasi tidak diterbitkan. Malang: Program Doktor Ilmu Ekonomi, Universitas Barwijaya.

39. Schryen, Guido; Wagner, Gerit\& Benlin, Alexander. 2015. Theory of knowledge for literature reviews: an epistemological model, taxonomy and empirical analysis of IS literature. Theory of Knowledge for Literature Reviews, pp. 01-22.

40. Shoji, Masahiro, et.al. 2012. Social Capital Formation and Credit Access: Evidence from Sri Lanka. World Development, Vol. 40, No. 12, pp. 2522-2536.

41. Sumarti, Titik. 2007. Sosiologi Kepentingan (Interest) dalam Tindakan Ekonomi. Jurnal Transdisiplin Sosiologi, Komunikasi, dan Ekologi Manusia. Vol. 01, No. 02, p. 283-293.

42. Tobin, Gerard A., Begley, Cecily M. 2003. Methodological Rogour Within a Qualitative Framework. Journal of Advanced Nursing. Vol. 48, No. 4, pp. 388-396.

43. Utama, A. 2003. Perusahaan Dalam Era Persaingan Global Melalui Aliansi Strategis. Kajian Bisnis. No. 30, Desember, 57-73.

44. Valentinov, V. 2004. Toward a social capital theory of cooperative 60rganization, Journal of Cooperative Studies, Vol. 37, No. 3, pp. 5-20.

45. Weis, L., \& Fine, M. 2000. Speed bumps: A study-friendly guide to qualitative research. New York: Teachers College Press.

46. Wollebaek, D., Selle, P. 2003. Participation and Social Capital Formation: Norway in a Comparative Perspective. Scandinavian Political Studies. Vol. 26-1.

\section{APPENDIX}

Table A - Dimension and Codes of Characteristic from the Model Analysis

\begin{tabular}{|l|l|l|}
\hline \multicolumn{1}{|c|}{ Dimension } & $\begin{array}{l}\text { Desciption and } \\
\text { Apriori Code }\end{array}$ & \multicolumn{1}{c|}{ Inductive Code Discovery } \\
\hline $\begin{array}{l}\text { Cooperative } \\
\text { Governance }\end{array}$ & $\begin{array}{l}\text { Trustworthiness; } \\
\text { expectation; } \\
\text { obligation }\end{array}$ & $\begin{array}{l}\text { Mutual Agreement; Governance Development; Principles of } \\
\text { cooperation; governance mechanism; Characteristic; involvement in a } \\
\text { cooperative environments; Cooperative entreprenurship; the ability of } \\
\text { the management }\end{array}$ \\
$\begin{array}{l}\text { Group } \\
\text { Cohesiveness }\end{array}$ & $\begin{array}{l}\text { Individual } \\
\text { attractions; Social } \\
\text { influence; } \\
\text { Satisfaction }\end{array}$ & $\begin{array}{l}\text { Perceptions of the member; Motivation of the members; appeal of the } \\
\text { member/member's interest; changes in the income level of the } \\
\text { member; charactersitic of the group; type of services for members; } \\
\text { incentive; rights and obligation of the group's member. }\end{array}$ \\
$\begin{array}{l}\text { Economic Activity } \\
\text { of Cooperative }\end{array}$ & $\begin{array}{l}\text { Participations; } \\
\text { Innovations; } \\
\text { Strategic activity; } \\
\text { Operational }\end{array}$ & $\begin{array}{l}\text { The role of both member and the management; Relationship between } \\
\text { member and the board/management; correlation between the } \\
\text { components of the organization, the procedural relationship between } \\
\text { members and the cooperative; norms, sanctions, and rules on the } \\
\text { performance of members of the cooperative }\end{array}$ \\
$\begin{array}{l}\text { Member's } \\
\begin{array}{l}\text { Participation- } \\
\text { Based } \\
\text { Cooperative } \\
\text { Development }\end{array}\end{array}$ & \begin{tabular}{l} 
The essence of member-based cooperative; Principle of participation. \\
\hline
\end{tabular} & \multicolumn{2}{|l}{} \\
\hline
\end{tabular}


Table B - Example of Quotes from the Interviews

\begin{tabular}{|c|c|}
\hline Case & Data \\
\hline $\begin{array}{l}\text { History of the Formation } \\
\text { of Joint Responsibility } \\
\text { System }\end{array}$ & $\begin{array}{l}\text { Board Member } 1 \# \text { 1: "the first step of establishment was based on the things that } \\
\text { were aimed toward increasing the revenue of each public member in the cooperative } \\
\text { environment" } \\
\text { Board Member } 2 \# 2 \text { : "Before it became a cooperation/cooperative this was an } \\
\text { association of the members from regular social gathering between a few unions, such } \\
\text { as the Mitra Manindo which is not restricted to women member, but rather it was a } \\
\text { union for those engaged in the sector of various mushroom cultivation, namely some } \\
\text { oyster mushroom, abalone, shiitake and cloud ear fungus. Started from there, it was } \\
\text { then continue to become a saving and loan business." }\end{array}$ \\
\hline $\begin{array}{l}\text { Operationalization } \\
\text { of Joint Responsibility } \\
\text { System }\end{array}$ & $\begin{array}{l}\text { Board Member } 1 \# 1 \text { : "The principal of joint responsibility that was developed is the } \\
\text { right pattern for us, women, because it matches with our togetherness." } \\
\text { Board Member } 2 \# 2 \text { : "The definition of Joint Responsibility is that every member must } \\
\text { be united in one voice and also each member has to be brave in facing the risk or be } \\
\text { bold to refuse when they have to. To be more specific according to the definition, } \\
\text { cooperative is a system that makes all the member obligation to the cooperative is a } \\
\text { shared responsibility among members on the basis of openness and mutual trust" } \\
\text { Board Member } 4 \# 4 \text { : "Well, according to the slides about cooperatives, the essence of } \\
\text { joint responsibility system is an effort to improve the quality of the person through } \\
\text { interaction between members." }\end{array}$ \\
\hline $\begin{array}{l}\text { Regulatory Elements in } \\
\text { the Joint Responsibility } \\
\text { System }\end{array}$ & $\begin{array}{l}\text { Board Member } 2 \# \text { 2: "We (as the board) have to focus as much as possible and be } \\
\text { professional. We always learn on how to improve the quality of ourselves as a } \\
\text { person." } \\
\text { Board Member } 2 \# \text { 2: "We have a very clear written rule as stated in the Mitra Manindo } \\
\text { profile. Such rule also exists in the society, right? Well, that also become part of the } \\
\text { joint responsibility group which is accompanied by companions." } \\
\text { Board Member } 4 \# 4 \text { : "Well, the Quran recitation is actually a kind of informal rule. It } \\
\text { isn't really. It is a binding rule, but at the same time it also not really binding. There are } \\
\text { many kind of invitation or recitation/study with different traits, some are routine acitvity } \\
\text { others can be an impromptu, for example, when a family member dies." }\end{array}$ \\
\hline $\begin{array}{l}\text { Social Capital Parameter } \\
\text { in the Joint } \\
\text { Responsibility System }\end{array}$ & $\begin{array}{l}\text { Board Member } 4 \# 4 \text { : "So in this case the member can pay for how much they can } \\
\text { afford, for example if there is a member who is unable to pay, then that just means } \\
\text { he/she had a dependent/mortgage. It won't be a problem if a member pays for their } \\
\text { share the next month. The group already understand, they usually talk about this in } \\
\text { the meetings including the gathering (/recitation)". } \\
\text { Group Member } 2 \# 2 \text { : "That kind of link/relation does exist within the cooperative } \\
\text { members. It is the same thing with handcraft exhibition, even our members often gets } \\
\text { a new business network outside Mandailing Natal, North Sumatera." }\end{array}$ \\
\hline $\begin{array}{l}\text { Group/Members' } \\
\text { Dynamics }\end{array}$ & $\begin{array}{l}\text { Group Member } 1 \# 1 \text { : "There will always be someone who strays from the rule. } \\
\text { However, we are prioritizing on the process of making all the member to have a } \\
\text { commitment." } \\
\text { Group Member } 1 \# 1 \text { : "The essence of joint responsibility system is to improve the } \\
\text { quality of the person through interaction between members." } \\
\text { Group Member } 3 \# 3 \text { : This coercion can be effective because the cooperative is also } \\
\text { giving something back to the group in a form of realization of shared goals/common } \\
\text { goals. [This coercion can be effective because the cooperative is giving back a reward } \\
\text { to the group when the shared goals is achieved]. From which was originally perceived } \\
\text { as a compulsion, it will then become a habit, I already had both bitter and good } \\
\text { experience of it." }\end{array}$ \\
\hline
\end{tabular}

